\title{
What makes a nationalist? Nationalism in the Dutch press coverage of Macedonia, 1991-1995*
}

\section{'New nationalism'}

'The repressed has returned and its name is nationalism. .' These words are the opening of the book Blood and Belonging (I993), written by the influential historian Michael Ignatieff. The book revolves around the characteristics of 'the new nationalism', its sudden emergence in the I990's, the dangerous 'ethnic' element it contained and its inherently antidemocratic nature. If anything, 'this return of the repressed' was associated with the dissolution of the Soviet Union and Yugoslavia. The disintegration of Yugoslavia especially had shown 'the civilized world' the ugly face of a returning -ism: ethnic cleansing, large-scale violence, rape, and the reproduction of dangerous national myths. The horrors in Bosnia especially were heralded as the final argument to settle once and for all that nationalism was simply a recipe for disaster, an ideology that had singlehandedly swept away the liberal democratic promise of an 'end to history' and instead presented a return to Europe's dark and bloody past. ${ }^{2}$

A widely held view during the Bosnian war was that Macedonia would be the next battlefield, either falling prey to internal ethnic conflict or land-hungry neighbours. ${ }^{3}$ But even as the ideology of nationalism was commonly blamed for everything which went wrong during the breakup of Yugoslavia, virtually no one in the West questioned the independence of the Republic of Macedonia, a state whose very existence was grounded in the belief that there existed a Macedonian nation, ${ }^{4}$ a Slavic population distinct from the neighbouring Serbs and Bulgarians. Thus, the architect of an independent Macedonia, president Kiro Gligorov, was not referred to as a nationalist. In fact, a Dutch newspaper article from November 1992 refers to him as someone who 'has kept the nationalists [the 'nationalist' opposition] in check'. ${ }^{5}$ In a similar vein, when there was a failed attempt on Gligorov's life in I995, media reported about 'nationalists' being behind the attack, implying that the president himself was not a nationalist. ${ }^{6}$

\section{In a world of nations}

This example should lead us to question both the meaning of nationalism and the comfortable view that is solely to be associated with 'them', 'the bad guys', rather than with 'us', the 'anti-nationalist' West. Michael Billig's argues in his successful Banal Nationalism (I995) that the idea that nationalism should be associated with the extreme, the irrational and/or the violent is a way of making nationalism the property of 'the other'. Through a narrow understanding of the term, 
'nationalism' becomes a problem of the geographical and political periphery, effectively reducing the ideology to an attribute of the non-Western world and extremist political movements.

Yet Billig claims that such a view has obscured the very real influence nationalism continued to exert in 'the West' - an area that is to this day still clearly divided into distinct nation-states. Instead of conforming to the dominant stereotype, the nationalism of the established Western nation-states is manifested in more subtle forms, being part of an everyday routine and common sense that remains unnoticed by most of the citizens it affects. As such, Billig proposes the use of the term 'banal nationalism' to cover those forms of nationalism which are responsible for the reproduction of (Western) nation-states on a daily basis. This daily routine can manifest itself in the use of physical 'national' items, such as flags or coins and paper money,7 but is equally represented in the areas of language and common sense. According to Billig, small everyday words can betray a worldview that takes for granted a context of nationalism. When politicians or newspapers talk about 'the' nation, or 'our' president, it remains often unexplained to which specific nation or president one refers to; instead, a specific background of nationalism is assumed in which the context of the utterance is taken for granted. 'The nation' is 'our nation' and 'our president' is 'our national president'.

Importantly, these banal forms of nationalism do not just reproduce the nation; they reproduce the nation in a 'world of nations'. 9 As other theorists besides Billig have noted, ${ }^{\text {to }}$ nationhood functions in an international context of nation-states that are inherently distinct from one another, yet similar in the use of the universal blueprint of nationhood and (theoretically) existing in mutual recognition of their respective national rights. ${ }^{\text {II }}$ The famous theorist of nationalism Ernest Gellner remarked that in the modern era of the nation-state 'a man must have a nationality as he must have a nose and two ears'. ${ }^{.2}$ In other words, within nationalist ideology it is not only assumed that 'we' naturally have a national identity, but that 'others' have one as well. Nationalism thus implies not only the reproduction of any particularnation, but encapsulates an intricate worldview that acknowledges and engages with an image of a world neatly divided into nations, and by extension, into nation-states. Importantly, such views are often not captured under the common stereotype of what is understood to be 'nationalism', and as such become 'natural' aspects of the world we live in. In this sense, nationalism, apart from being a particular ideology linked to particular nations (e.g. 'Macedonian nationalism', 'Dutch nationalism', etc.), is equally 'the [universal] ideology by which the world of nations has come to seem the natural world [emphasis added]'. ${ }^{\text {I3 }}$

\section{Media and nationalism}

According to Billig, one source in which this naturalized nationalist worldview can easily be discerned is the media. ${ }^{\mathrm{I}}$ Through the selective naming of nationalism, news reports reflect on common sense ideas about what is 'nationalism' and what is not. By extension, such distinctions show which aspects of nationalism are considered problematic and which aspects are considered 'natural', remaining unnamed and unquestioned. As a first step to approach this claim made in relation to the media, a specific choice has been made here to work with newspapers. Not only are newspapers, befitting the theory of banal nationalism, quite literally 'everyday' items; unlike television and radio, newspapers are more readily accessible and can provide us 
more easily with a solid body of (written) sources. Equally, the use of written sources will make the essential search for the terms 'nationalism', 'nationalist' and 'nationalistic' far more straightforward.

The second step concerns the choice for a specific case. Following the assumption that news reports on 'nationalism' thus reflect on the acceptance and rejection of specific aspects of nationalist ideology, this article concerns itself with the Dutch press coverage of a case in which 'nationalism' was a 'hot topic': that of Macedonia during the breakup of Yugoslavia (I99I-I995). Newspapers provided extensive coverage of what is known as the 'Macedonia name dispute'. In this conflict, Greece claimed that the name of its newly independent neighbour constituted a danger to Greece's cultural and territorial integrity. Holding a similarly named province that covers most of the ancient kingdom of Macedonia, the Greek state argued that the Republic of Macedonia was trying to usurp 'Greek' land and history. At the same time, the Macedonian Republic faced internal struggles in which nationalism was a topic of interest as well; more than one doomsayer propagated that Macedonia could be the centre of the next 'Balkan war'. ${ }^{15}$ As such, there was also a sizeable interest in 'extreme Macedonian nationalism' and the separatist sentiments of Macedonia's Albanian minority.

By looking at the use and disuse of the words 'nationalism', 'nationalistic' and 'nationalist(s)' in newspaper articles relating to these subjects, this study asks whether and how nationalism, both as a topic (as a descriptive term) and a frame of reference (as a specific discourse), influenced the press coverage of the Macedonian case. Essentially, this two sided approach creates two distinct forms of nationalism. On the one hand, we are concerned with references to 'particular' forms of nationalism, that is, nationalism related to a specified nation. This type would include for instance references made to 'Greek' or 'Macedonian' nationalism. Of this type, we will want to know where it points to descriptively: who is considered to be a nationalist, and what is considered to be nationalism?

Yet at the same time we are equally concerned with the aforementioned 'banal' expressions of nationalism, that is, those arguments or comments that take for granted a 'world of nations' as the 'natural' state of affairs. Dutch journalists and external contributors might not be Macedonian or Greek nationalists in a strict sense, but this does not necessarily mean that they cannot be considered nationalist in a more banal sense. The second analysis thus revolves around the question how a nationalist framework might have influenced the press coverage itself. As sociologist Michael Schudson points out, news is inherently 'framed' within the 'little tacit theories' which structure our world. 'Consciously or unconsciously, every narrative makes assumptions about how the world works, what is important, what makes sense, and what should be. ${ }^{\text {I } 6}$ This study takes banal nationalism to be one of the 'little tacit theories' that provided a framework for the Dutch news coverage on the breakup of Yugoslavia. For if nationalism is indeed endemic in our cultural and political life, as Billig argued, the language used in covering the breakup of Yugoslavia in the Dutch press should reveal this endemic condition: its rhetoric, use of words and arguments should in one way or another revolve around a worldview that takes the world of nations for granted. 


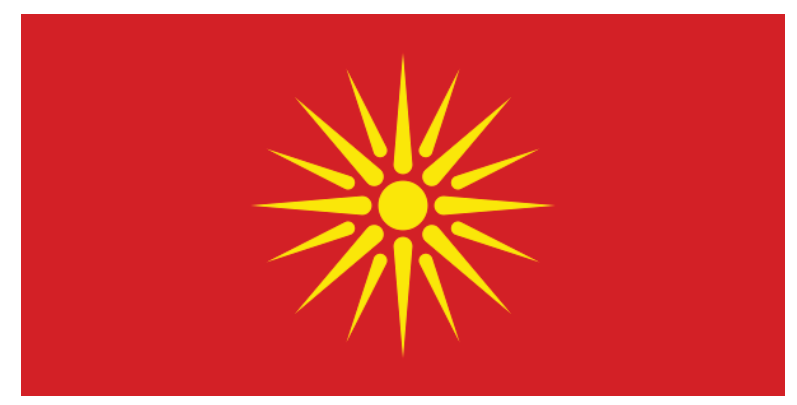

III. 1: The original flag of the Republic of Macedonia showing the Star of Vergina, a symbol associated with Alexander the Great. Greece objected to its use, and the flag was ultimately replaced by a new design that incorporated a sun rather than the disputed star.

Source: http://en.wikipedia.org/wiki/File:Flag_of_the_Republic_of_Macedonia_1992-1995.svg

\section{Analysis of newspaper articles}

For this study, three national newspapers have been examined: Trouw, NRC Handelsblad (NRC), and Het Algemeen Dagblad (AD). The timeframe covers the first five years of Macedonian independence, starting a month before the secession of Macedonia from Yugoslavia 8 September I99I), and ending in October I995, when Greece lifted its embargo of Macedonia that was instated as a response to the Macedonia name dispute. This timeframe shows a large overlap with the Bosnian war and represents a period in which the breakup of Yugoslavia as a whole was a widely covered news topic. A selection of those articles within this timeframe that dealt with topics concerning nationalism in relation to Macedonia led to a collection of 280 articles, ranging from editorials, news articles and letters to the editor (LTE's).

Since the goal of this research was not to directly study the press as an institute in itself, but rather the possibility of nationalist framing in relation to the breakup of Yugoslavia, the selection of newspapers has mainly been guided by practical concerns. As such, the first reason for specifically choosing the three newspapers in questionis the fact that these are all major national newspapers, split between quality (Trouw, NRC) and popular (AD) press, ${ }^{17}$ that published a significant amount of news and background articles on the breakup of Yugoslavia. The second concern was accessibility; $N R C$, Trouw and $A D$ were all available online through the online database of LexisNexis, which allowed for the (pre)selection of articles on the basis of search terms (in this case, simply 'Macedonië). The digital availability of these sources allowed for the study of a relatively long(er) timeframe as the selection of online sources was far less time consuming than research done through physical (microfiche) archives.

In turn, from the search results of those articles that included the term 'Macedonië', a thematic selection was made by focussing on nationalism in its broadest sense, including those articles that dealt with the Macedonian independence, nation-building in Macedonia, the name conflict with Greece, minority questions, and background articles concerning the history of Macedonia and/or the Macedonian people.

To start, the first analysis of the final selection of articles concerned the use of the terms related to nationalism: who was considered to be a 'nationalist', and what was considered to be 'nationalist(ic)' or 'nationalism'? ${ }^{18}$ Two aspects were taken into account here: (I) is the terminol- 
ogy associated with a specific national group? (e.g. Greek, Macedonian, etc.); (2) is the terminology used in a positive, neutral or negative sense? To categorize articles in this manner, the following criteria have been used. A reference was considered to be 'negative' when it described nationalism as a cause of violent or non-violent conflict, when it was used to describe someone whom the author disagreed with, or when the term was linked to extremism, irrationality and/ or backwardness. References were classified as 'positive' when writers identified with causes that they themselves classified as 'nationalist', or when nationalism was seen as a potentially benign ideology. Lastly, references were considered to be 'neutral' when they conveyed no direct normative assertions about nationalism, or in other words, were lacking the criteria for positive and negative references.

The second analysis consisted of looking for a more elusive aspect of the news coverage: those forms of nationalism that were not classified by the press as being 'nationalist', the signs of a 'nationalist frame' through which the news coverage was possibly filtered. Following Billig's view that nationalism is in possession of its own discourses of hegemony, ${ }^{19}$ this part of the research should be classified as a discourse analysis. It focussed on analysing how journalists and external contributors argued and reasoned about the aforementioned nationalist themes, looking beyond those issues that they themselves classified as 'nationalist'. Do these people take a specific stance in the naming issue, and if so, with what sort of arguments do they defend their views? How do their writings describe and evaluate the recent independence of Macedonia? By contrasting these possible instances of 'unnamed' nationalism to the explicit references to nationalism, a picture will emerge about those assumptions and values that underlie the coverage of nationalist themes.

A first look at the use of terms related to nationalism already reveals a clear picture. In the news coverage of Macedonia (tables I-3), nationalism is associated mainly either with its Greek variant or that of the Macedonian opposition (see table I). Macedonian nationalism here has been split in two different categories since most references to Macedonian nationalism did not relate to a generic 'Macedonian nationalism', but very specifically to the ideology of those who were opposed to the government coalition of Gligorov (especially in the form of the largest opposition party, VMro, ${ }^{20}$ commonly described as 'extremely nationalistic'). This is an important distinction to which we will return later on.

Secondly, most references to nationalism have a negative connotation - especially in the context of Greek and Macedonian-opposition nationalism (see table 3). Several factors are of importance here. Above all, there are strong implicit and explicit links between nationalism and extremism. Thus, 'Macedonian nationalism' is often seen as synonymous with the ideas of vmro, commonly labelled as 'extreme', 'ultra', or 'fiery nationalistic'. Even if the labels such as 'extremist' are missing, the context usually indicates that we are dealing with an 'extreme' form of nationalism. For instance, NRC-editor Peter Michielsen, responsible for a large share of the articles on Macedonia, uses 'nationalism' and 'extremism' as synonyms: 'both populations [Albanians and Macedonians] have their own extremists - the nationalists are even the largest opposition party in the Macedonian parliament'. ${ }^{21}$ In a similar vein, another article by Michielsen about the Albanian minority in Macedonia uses 'Macedonian nationalists' in one sentence, only to change these nationalists into 'Macedonian extremists' in the next. ${ }^{22}$ Such views are commonplace; all instances of extremism found refer directly or indirectly to these so called 'nationalist groups'. 
References to Greek nationalism relate mainly to Greece's role in the Macedonia naming dispute. In response to the name of its newly independent neighbour, Greece blocked the un ascension of Macedonia and placed an embargo on the former Yugoslav republic, while parts of the Greek population organised huge demonstrations and started to boycott products originating from countries deemed 'too supportive' of Macedonia, which included the Netherlands. ${ }^{23}$

In the Greek case, nationalism is seen as a surplus phenomenon, reduced to specific psychological states and 'irrational' behaviour. As such, peace activist Mient Jan Faber calls the Greek reaction to the Macedonian namedispute a 'nationalistic psychoses with typical Greek characteristics'. ${ }^{24}$ Other articles mention the 'irrational', 'hysterical' and 'emotional' character of the Greek 'obsessions' with the new Macedonian state, ${ }^{25}$ attributes commonly closely associated with the ideology of nationalism itself. ${ }^{26}$ Greek nationalism, as NRC journalist Frans Hasselt puts it, 'is somewhat foolhardy, it is as if the Greeks want to say, look at what has become of us. To face the wicked and ignorant outside world, we have to take refuge in nationalism, even though we know you can't really do that'. ${ }^{27}$ In Hasselt's view, even the 'nationalistic' Greeks know that in the modern world, nationalism is an unacceptable and malignant ideology of the periphery.

These negative associations with nationalism are further strengthened by the vocabulary used by those who explicitly side with either the Greek or Macedonian cause. In a LTE published in $A D$, pro-Greek historian W. van Loon accuses 'pro-Macedonian' activist Els de Groen of dancing to the tunes of 'Slavo-Macedonian nationalism'. ${ }^{28}$ De Groen in turn replies with an article in which she distances herself from this accusation of 'nationalism' of Van Loon and puts the blame of current troubles on nationalists in general, whether they are Greek, Albanian or Macedonian. ${ }^{29}$ Similar opinionated articles follow this trend; both pro-Greek and pro-Macedonian articles take nationalism to be something negative, and use it descriptively strictly to describe those whom they disagree with. ${ }^{30}$

Apart from these negative references, there were some positive and neutral descriptions of nationalism, though these were few and far between. AD-editor Othon Zimmerman, for example, argues that the 'moderate nationalism' as propagated by Gligorov is essential to the stability of Macedonia - making it the only reference in which the Macedonian president is directly associated with the ideology of nationalism $\cdot^{3 \mathrm{I}}$ However, even this rare instance in which nationalism is seen as a potential source of good is accompanied by the typical stereotypes concerning nationalism. Thus, for nationalism to be something 'good', it needs to be 'moderate'. The fact that nationalism without any qualification is still by default 'extremist' is made clear by the fact that the same article refers to 'Macedonian nationalists' as the most probable suspects of the violent attack on Gligorov.

Naturally, it shouldn't come as a surprise that negative stereotypes about nationalism were invoked en masse during the Yugoslav conflicts. However, the analytic value of this stereotype lies primarily in pointing to those forms of nationalism that remain 'unnamed'. The most striking fact is without doubt that the nation-state of Macedonia is unmade as being a nationalist construct. This means that on the one hand, Macedonia is continuously flagged as the homeland of the 'Macedonian people' and that its existence is acknowledged as being founded in the presumed existence of a Macedonian nation. On the other hand, this clear characterization of Macedonia as a nation-state is not associated with the negative term 'nationalistic' or seen as related to the concept of nationalism. 
This 'unmaking' of nationalism is powerfully illustrated by articles that deal with Gligorov. As the first president of an independent Macedonia, Gligorov was highly involved with the ideology of nationalism. But as someone who was also seen as being a beacon of reason in the otherwise 'irrational' Balkans, journalists seemed to feel that this man could simply not be associated with nationalism, let alone to be called a 'nationalist'. To deal with this paradox, Michielsen praises Gligorov as 'the Father of the Macedonian independence'. ${ }^{2}$ But what was this independence if not a national(ist) one? Quite similar, both in the $A D$ and Trouw, Gligorov is called the 'father of the fatherland'. ${ }^{33}$ Interviews with the president go along with this view of Gligorov as the reasonable anti-nationalist, even though it takes little effort to reveal the nationalist rhetoric Gligorov himself uses. ${ }^{34}$ In an interview with Trouw journalist Nicole Lucas, he is quoted as stating:

'Only if this country is called Macedonia, can we call ourselves Macedonians. And only in that way can we differentiate ourselves from the Greeks, the Bulgarians and the Serbs, who all think that we belong to them'. ${ }^{35}$

There can be no doubt who this 'we' refers to; it is an ethnic Macedonian nation, those Slavic speakers who had been termed 'Bulgarophone Greeks' by the proponents of the Megali Idea ('Greater Greece'), considered 'South-Serbs' in the interwar Kingdom of Serbs, Croats and Slovenes, or simply called Bulgarians by the champions of a Greater Bulgaria..$^{36}$ Similar rhetoric was espoused by Gligorov during his speech in the European parliament in I993, of which Trouw quoted the following passage: 'All people[s] have the right to choose themselves the name of the country they live in. We choose Macedonia, because the Serbs used to call us Serbs, and the Bulgarians considered us Bulgarians'. ${ }^{37}$

In both cases, Gligorov's national 'we' (or 'us') does not cover all of the Macedonian citizens; it excludes for instance the Albanian and Turkish minorities (groups whose 'differentiation' has often been taken for granted in many of the modern Christian Balkan-states). Similarly, it positions Macedonia as a state that derives its legitimacy from the existence of a Macedonian nation (and as such, Gligorov is not saying anything which can't already be derived from the aforementioned I99I constitution of Macedonia). Even though such rhetoric should thus strictly be classified as falling under the umbrella term of 'ethnic nationalism', this does by no means suggest that the Macedonian president can be put on the same level as his Croat and Serbian counterparts. What it does show however, is how Gligorov can use clear-cut nationalist rhetoric without being branded a nationalist by the Dutch press.

As stated, the tendency to disassociate Gligorov from the concept of nationalism is representative of a broader trend that tends to naturalize the Macedonian nation-state. Such views are most certainly not restricted to those who sympathized with Macedonia in its conflict with Greece. Historian Van Loon ends his plea for the Greek cause with the statement that the 'Slavo-Macedonians', in spite of their cultural 'theft' of 'Greek' heritage, 'like all other [peoples], have a right to their own state' $3^{8}$ In spite of using the term 'nationalism' to negatively describe those differing from his own opinion, Van Loon takes for granted the prime principle of nationalism: the ideal of the congruence between nation and state. 39

Van Loon is by no means alone in taking the existence of distinct peoples with a natural 
right to national self-determination as a given. When it comes to Macedonia, journalists and external contributors seem to have no trouble in reproducing national histories that revolve around continuity of nationhood and self-determination. Thus, when Michielsen states that 'the Macedonian history' is a 'chain of disasters', he starts this sorrowful epic with the flourishing of Slavic churches in the medieval Macedonia of the $10^{\text {th }}$ century. The tone is set: the Macedonian history is that of a distinct and oppressed Slavic people:

'Historical losers, the Macedonians: so many wars, and they themselves never got anything out of it except for a new master, always one with a harsh hand. (...) The liberation came only in I945, with Tito, when they were out of the sudden allowed to have their own republic of Macedonia, only then were they allowed to name themselves after the land in which they had lived for thirteen centuries [emphasis added]'.40

Lucas equally laments the sorrowful history of the Macedonians, stating that the Macedonians themselves were 'rarely in charge' during their ten centuries long and 'turbulent' history. ${ }^{4 \mathrm{I}}$ In a similar vein, De Groen describes Albanians and Macedonians as historically oppressed nations, emerging from ' 500 years of Turkish oppression' only to be overlooked by the European powers in the I9I3 London peace settlement.42

Such statements are nationalist in two ways. On the one hand, they make history revolve around distinct and stable national identities, projecting the nation back into a faraway past in which it most certainly did not exist.43 On the other hand, they focus on the degree of freedom these presumed national entities enjoyed, contrasting concepts such as foreign oppression with collective freedoms in a national context. Naturally, these statements are normatively charged. While Michielsen challenges Greek claims to national continuity and describes the Greeks as cherry picking arguments out of the 'bottomless grab bag of history' in the Macedonia name dispute, he sees no problem in narrating a glorious epic about a thirteen centuries old Macedonian people that ultimately find freedom by acquiring a republic of their own in Tito's Yugoslavia of Brotherhood and Unity. ${ }^{44}$ Yet while thoroughly nationalist, these examples are not referred to as 'nationalism'; they disappear from sight against the stereotype of nationalism as an extremist and violent ideology of 'the other'. Articles might confer different views about the name that would be (in)appropriate for the new Republic of Macedonia and its inhabitants, but no one questions the existence of a distinct Slavic people with 'natural' rights to a political unit of their own. Such rights are taken for granted and not up for debate; they seem to provide the parameters, the 'frame', of the debate. 


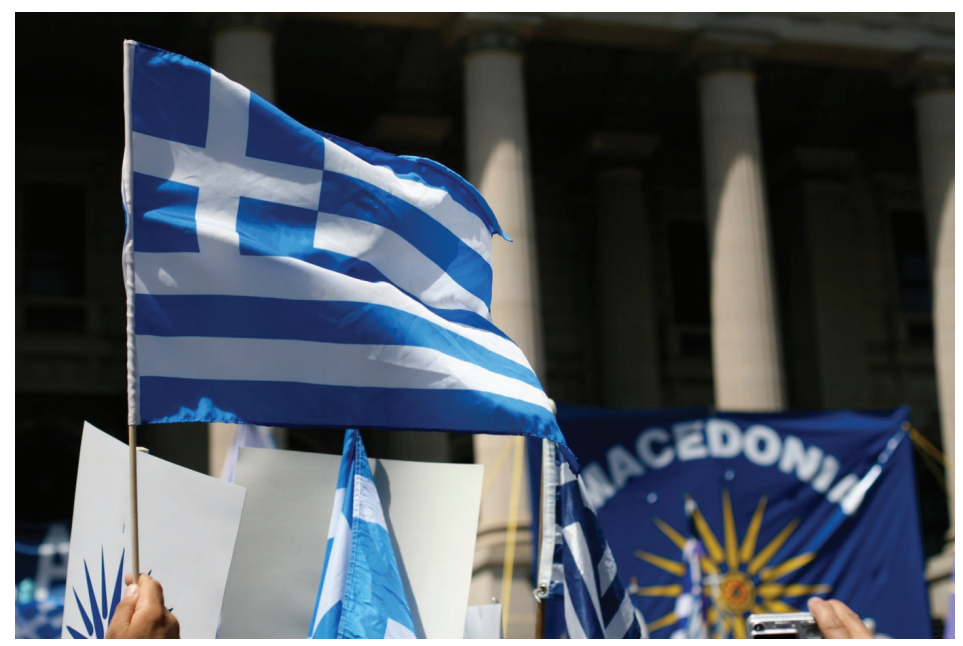

III. 2: The Macedonia name-dispute is yet to be resolved. This picture shows Greek and Greek-Macedonian flags being waved at a 2007 protest in Melbourne. Photo by George Papadopoulos.

Source: http://commons.wikimedia.org/wiki/File:Macedonian_Greek-Australians_rally_in_Melbourne,_Greek_ flag.jpg

\section{Comparison and conclusion}

Having considered the use and disuse of words related to nationalism, let us take a step back and reflect on the implications these findings have for the Dutch press. When it comes to the breakup of Yugoslavia and the Bosnian war in specific, there have been several studies that have criticized the news coverage of the Western press. ${ }^{45}$ Can such studies help to contextualize the results of this analysis?

The strongest accusation that has been leveled at the Western press has without doubt been that of practicing 'journalism of attachment'. Coined by former ввС-correspondent Martin Bell, the term 'proposes that reporters are participants in the conflicts they report and, as a consequence, take part in the public debate about the conflict'. ${ }^{6}$ In this process, journalistic objectivity was secondary to the promotion of an intervention agenda and the shaping of popular opinion.

As part of the Western world, the Netherlands has not been able to avoid this generalized criticism. In her dissertation on the Dutch newspaper coverage of the Bosnian war, Nel Ruigrok argued that journalists covering the Bosnian war had let themselves to be guided by moral rather than objective journalistic imperatives, focussing on influencing public opinion and intervention debates instead of serving as impartial mediators 'between the events and the audience'. ${ }^{4}$ The NIOD-report on Srebrenica equally reprimanded the Dutch press, stating that they had, together with politicians, created a stereotype and simplified view of the conflicts in Bosnia. $4^{8}$

The clearest consequence of this 'attached' type of journalism was the creation of a dichotomy between 'good guys' and 'bad guys'. Thus, NRC-editor Raymond van den Boogaard was severely criticised by his colleagues when he wrote about the lack of evidence for large scale occurrence of rape in Serbian prison camps. ${ }^{49}$ The prevailing view of the 'good guys, bad guys' distinction had made such journalistic doubts seem as amoral because they interfered with the goal of journalists to promote and influence intervention debates. 
Even though Macedonia escaped the horrible violence that engulfed Bosnia, there is no doubt that here too a picture of 'good guys' and 'bad guys' prevailed. Most importantly, this distinction, as shown in the previous section, was effectively articulated through the selective naming of 'nationalism'. Praised by journalists for his moderate politics, a 'good guy' such as Gligorov stayed clear of the stigma of nationalism. Instead, terms related to nationalism were reserved for 'bad guys': the violent and extremist opposition at the Macedonian home front and those 'hysterical' and 'nationalist' Greeks that objected to the name of the newly independent republic. As can be seen in table I, these two stereotypical 'bad guys' accounted for most of the references made to nationalism. Befitting the relation of 'nationalism' to 'bad guys', such references often had a negative connotation, as can be seen in table 2. At the same time, none of the articles studied spoke out against an independent Macedonian state; the national independence in itself was clearly not considered to be something that could be criticised. In this spirit, references to a generic Macedonian nationalism were not only significantly lower (less than half than the number of references made to either Greek or Macedonian nationalism associated with the opposition), but also evaluated far more positively (see table 3 ). It was the only category (leaving aside the undefined references to nationalism) that included a positive description, and it had a far larger proportion of neutral references than any of the other categories.

This selective naming was closely connected to the perception of the nationalism associated with 'good guys' and 'bad guys' respectively. As shown, there is no doubt that Gligorov himself used nationalist rhetoric in order to express his views in the international arena. Yet he and Macedonia, both as a state and a distinct people, were perceived as being in a defensive underdog position, trying to preserve internal order while being attacked economically and diplomatically by a more powerful neighbour. Equally, Gligorov was seen as a peaceful person, and without doubt rightly so in the context of the disintegration of Yugoslavia. Such a characteristic made it virtually impossible for him to be associated with nationalism, which was often considered synonymous with violence and aggression. One only has to think of the contrast evoked by the labelling of those who were claimed to be after the attack on Gligorov simply as '(Macedonian) nationalists'.

While the aforementioned NIOD-research concerning the Dutch press had a very different methodology, case (mostly focussing on Bosnia) and selection of sources, there is an interesting comparison to be made here. Most of the criticism from the NIOD-report was levelled at the quality press, who had generally been more involved with opinionated news coverage than its popular counterpart. As such, the $A D$, (popular) had (implicitly) been given a more favourable review than a quality newspaper like the $N R C^{5 \circ}$ When we take the selective naming of nationalism to be a form of bias, the data of this research seem to support such a conclusion. If we look at table I, we can see that the references to nationalism are, in the case of the $A D$, more evenly spread across the different national groups than in the case of the NRC, which focussed more strongly on the stereotypical 'bad guys', i.e. the 'nationalist' Greeks and 'extreme nationalist' Macedonians. Trouw seems to be fall somewhere in between the other two newspapers, as it did focus more strongly on one group of 'bad guys', the Macedonian nationalist opposition, but hardly concerned itself with manifestations of Greek nationalism. While this comparison with the NIOD-report should be approached cautiously (as the data of this study included LTE's), it does seem to point at the selective naming of nationalism as a manifestation of media bias, as those 
parties that are favoured by the press will rarely be termed nationalist and vice versa.

Despite the general tendency to project nationalism on 'the other', it is clear from this analysis that nationalism cannot simply be disassociated from the Dutch press itself. Journalists and external contributors openly professed nationalist views in their conceptions of the troubles of Macedonia; they might condemn what they considered to be extremist forms of nationalism, but had no trouble in sympathising with nationalist causes that struck them as just or natural. They took for granted a 'world of nations' in which the Macedonians simply claimed the universal political privileges that 'naturally' flowed from fully fledged nationhood. Following the analysis put forward in this article, it thus seems fair to state that 'nationalism' was indeed one of those 'little tacit theories' that framed the Dutch news coverage of Macedonia, ${ }^{5 \mathrm{I}}$ both as a selectively applied descriptive term, and as a discourse underlying the discussions and framing of news items concerning Macedonia.

If anything, this article points to the fact that the influence of nationalism is a very real part of the news coverage, even in countries that have often styled themselves as 'anti-nationalist', a postwar sentiment that was arguably all the stronger in the context of the I990s 'resurgence' of nationalism in the Balkans..$^{2}$ In many ways then, this article underlines the validity of Billig's thesis of banal nationalism. Articles on Macedonia, even if showing some conflicting pro-Macedonian and pro-Greek views, were, to use Billig's words, 'likely to assume those general themes of nationalism that take for granted the naturalness of a world of nations' ${ }^{53}$ Yet to this we could add that banal nationalism is not only related to the forgetting of 'our' own nationalism, as Billig primarily argued. The sympathy for the newly emergent and struggling Macedonian nation-state made many equally forget about the nationalism that provided the most basic ideological fundaments for an independent Macedonia. In our modern 'world of nations', there are few things more 'self-evident' and banal than the statement that the 'Slavo-Macedonians, like all other [peoples], have a right to their own state'. ${ }^{54}$

Neither the press nor the public is helped by this dichotomy that sees nationalism only in extremes, the political periphery, or short outbursts of irrationality. It reduces our understanding of one of the most powerful ideologies in the modern world to a simple distinction between 'good guys' and 'bad guys' and presents us with a false choice between 'nationalism' and 'non-nationalism'. Most importantly perhaps, such a view fails to question the 'natural' state to which the world is supposed to return to once it has been rid of those stereotypical manifestations of nationalism, one that is without doubt nationalist even if it is so in a more banal sense. And just as extremism is not a synonym for nationalism, banal is not necessarily a synonym for benign. 
Table 1: Associated actors/national groups for references to nationalism ${ }^{55}$

\begin{tabular}{|l|l|l|l|l|}
\hline Nationalism reference: & NRC & Trouw & AD & Total \\
\hline Undefined & 5 & 2 & 6 & 13 \\
\hline Macedonian & 4 & 4 & 5 & 13 \\
\hline Macedonian (opposition/vMro) & I6 & I2 & 5 & 33 \\
\hline Greek & I7 & 3 & 9 & 29 \\
\hline Other & 4 & 4 & I & 9 \\
\hline Total & 46 & 25 & 26 & 97 \\
\hline
\end{tabular}

Table 2: (Implicit) judgement carried by the terminology (i.e. 'nationalism', 'nationalist', 'nationalistic') per article

\begin{tabular}{|l|l|l|l|l|l|}
\hline & Positive & Neutral & Negative & Positive and Negative & Total \\
\hline NRC & 0 & 8 & 33 & I & 42 \\
\hline Trouw & 0 & 5 & I5 & I & 21 \\
\hline AD & 0 & 2 & 24 & I & 27 \\
\hline Total & 0 & I5 & 72 & 3 & 90 \\
\hline
\end{tabular}

Table 3: Actor/national group linked to judgement (when both positive and negative references were related to different groups in the article, they have been split in this table)

\begin{tabular}{|l|l|l|l|l|l|}
\hline Nationalism: & Positive & Neutral & Negative & Positive and Negative & Total \\
\hline Undefined & o & 4 & 9 & I & 14 \\
\hline Macedonian & I & 3 & 6 & I & 11 \\
\hline $\begin{array}{l}\text { Macedonian } \\
\text { (opposition/vMro) }\end{array}$ & 0 & 4 & 33 & 0 & 37 \\
\hline Greek & 0 & 5 & 23 & 0 & 28 \\
\hline Other & 0 & 2 & I4 & 0 & 16 \\
\hline
\end{tabular}




\section{Notes}

*) This article is based on the MA-thesis "The stepchildren of the Balkans': how nationalism affected the Dutch press coverage of Kosovo and Macedonia during the breakup of Yugoslavia, I99I-I995'. An edited version of this thesis, including an overview of primary source material can be found on:

http://issuu.com/jongehistorici/docs/35michelvanduijnen (retrieved on 8 February 20I3). I would like to thank prof. dr. Susan Legêne and prof.dr. Pál Nyíri for feedback on the thesis and dr. Jonathan Hearn for reviewing an earlier draft of this article.

I M. Ignatieff, Blood Q belonging: journeys into the new nationalism, Farrar, Strauss and Giroux, London I993.

2 T. Nairn, Face of nationalism: Janus revisited, Verso, London I997, p. 58.

3 E.g., H. Aben, 'Landen Eg falen bij brand op de Balkan', AD, 24 October I992; E. Mulder, 'De kaart van de Balkan maakt van het arme Macedonië een onheilspellend landje', Trouw, I7 May I993; 'Belgrado overweegt buurland Macedonië te erkennen', Trouw, 3 October I995.

4 Preamble of the I99I Macedonian constitution. See: http://www.servat.unibe.ch/icl/mkooooo_.html (accessed 7 February 2013).

5 N. Lucas, 'Gligorow: Kans op Balkanoorlog', Trouw, ro November I992.

6 'Nationalisten verdacht van aanslag op president Macedonië', AD, 5 October 1995; 'President Gligorov buiten levensgevaar', Trouw, 4 October I995; P. Michielsen, 'Skopje speculeert over daders van aanslag', NRC, 4 October I995.

7 Billig, Banal nationalism, p. 4I.

8 Billig, Banal nationalism, p. Io9.

9 Billig, Banal nationalism, chapter 4.

Io E.g., Y. Tamir, 'Theoretical difficulties in the study of nationalism', in: Ronald Breiner (ed.), Theorizing nationalism, Sunny press, Albany I999, p. 67-90; and A. Wimmerand \& N.G. Schiller, 'Methodological nationalism and beyond: nation-state building, migration and the social sciences', in: Global networks 2, 2002, p. $30 \mathrm{I}-334$

II Billig, Banal nationalism, p. 83 .

I2 E. Gellner, Nations and nationalism: new perspectives on the past, Cornell University press, Ithaca I983, p. 6.

I3 Billig, Banal nationalism, p. 37.

I4 Billig, Banal nationalism, p. Io9-II9.

I5 See for example: W. Hagan, 'The Balkans' lethal nationalisms', in: Foreign affairs, 78, July/August, I999.

I6 M. Schudson, The sociology of news, Norton \& Company, New York 2003, p. 35.

I7 P. Bakker \& O. Scholten, Communicatiekaart van Nederland, Bohn Stafleu van LoghumHouten, Houten I997, p. I4-I5.

I8 In the data used for the tables I-3, the use of the words in quotations has been ignored since they do not represent the use of the word by the author, but of the person quoted.

I9 Billig, Banal nationalism, p. I2.

20 VMro: Vnatresno-Makedonska Revolucionerna Organizacija (Macedonian Revolutionary Organization).

2I P. Michielsen, 'Macedonië; vn voor het eerst preventief', NRC, I4 December I992.

22 P. Michielsen, 'De vrede staat sterk op de tocht in Macedonië; die Albanezen geven niet, ze nemen alleen maar in de coalitie; voor het zwaaien met de Albanese vlag ga je de gevangenis in', NRC, 24 November 1992.

23 H. Poulton, Who are the Macedonians? Indiana University Press, London 2000, p. 218.

24 M.J. Faber, 'Griekse obsessies over Macedonië', Trouw, 8 June I994.

25 E.g., J. Schils, 'Grieken piepen pas als Eu de geldkraan dichtdraait', AD, 5 April I994; 'Brussel, Athene en Skopje’, NRC, 7 April I994; P. Michielsen, 'Irrationeel Athene brengt de vrede in gevaar', NRC, 27 August I994.

26 Billig, Banal nationalism, p. 56.

27 F. van Hasselt, 'Grieks nationalisme heeft iets baldadigs', NRC, I7 December I992.

28 W. van Loon, 'De Groen doet Grieken in "Macedonische zaak” tekort', AD, I8 January I994.

29 E. de Groen, 'Dromen met 'Groot' ervoor leiden tot oorlog; erkennen van minderheden voor nationalisten onverteerbaar', $A D, 26$ January 1994.

30 E.g., L. Topaltzikis, 'Macedonië (5)', AD, I6 April I994; Michielsen, 'Irrationeel Athene brengt de vrede in gevaar', and Faber, 'Griekse obsessies over Macedonië'.

3I O. Zimmerman, 'Macedonië: een klein kruitvat, AD, 7 October I995.

32 P. Michielsen, 'Hoeveel Albanezen telt Macedonië?’, NRC, I4 October I994.

33 'Verdeeld Macedonië wankelt naar eerste verkiezingen', Trouw, I5 October I994, and O. Zimmerman, 'Gligorov:

“Grieken moeten kalmeren”, AD, I6 April I994. 
34 Zimmerman, 'Gligorov', and Lucas, 'Gligorow'.

35 Lucas, 'Gligorow'. For similar rhetoric, see the following article on Gligorov's speech to the European parliament: 'Gligorow smeekt om erkenning Macedonië', Trouw, 28 January I993.

36 Gligorov is referring here to the claims that have historically been made about the national 'belonging' of the Slavic speaking population of the region of Macedonia. Interwar Serbia considered these Slavs to be 'South-Serbs', while Bulgaria argued that they were in fact Bulgarians. Greece tried to deal with its Slavic population in GreekMacedonia by referring to them simply as 'Slavophone Greeks'. See: L.M. Danforth, 'Claims to the Macedonian identity: the Macedonian question and the breakup of Yugoslavia', in: Anthropology today, 4, I993, p. 3-Io.

37 'Gligorow smeekt om erkenning Macedonië', Trouw, 28 January I993.

38 W. van Loon, 'Griekenland moet met EG situatie op Balkan stabiliseren', NRC, I4 July I992.

39 Here we can recognize Ernest Gellner's definition of nationalism primarily as 'a political principle that holds that the political and the national unit should be congruent.' Gellner, Nations and nationalism, p. I.

40 P. Michielsen, 'Het bevroren hart van de Balkan; in Macedonië volgen de rampen elkaar op', NRC, 28 November 1992.

4I N. Lucas, 'Na tien eeuwen: “Een onafhankelijk Macedonië willen we allemaal”', Trouw, i7 February I992.

42 E. de Groen, 'Macedoniërs en Albanezen: de stiefkinderen van de Balkan', AD, 8 January I994.

43 This is especially problematic for the Macedonian case; the term 'Macedonians' to describe a specific Slavic people only emerged in the context of the rise of nationalism in the late $19^{\text {th }}$ century. There is no evidence for a specific Slavic Macedonian identity in any sense in earlier ages. See: Danforth, 'Claims to the Macedonian identity'.

44 P. Michielsen, 'Geen euforie in Eg over Bosnië en Macedonië’, NRC, I5 December I992.

45 E.g., P. Brock, 'Dateline Yugoslavia: The Partisan Press', in: Foreign Policy, 93, I993-I994, p. I52-I72; J.K. Sadkovich, 'The response of the American media to Balkan neo-nationalism', in: S. Meštrović (ed.), Genocide after emotion: the postemotional Balkan war, Routledge, London 1996, p. II3-I57; P. Hammond \& E.S. Herman (eds), 'Degraded Capability: The Media and the Kosovo Crisis', Pluto Press, London 2000. For examples concerning the Dutch case, see the 2002 NIOD-report on Srebrenica on http://www.srebrenica.nl/ (accessed 3I October 20I3) and N. Ruigrok, Journalism of attachment: Dutch newspapers during the Bosnian War, Het Spinhuis, Amsterdam 2002.

46 Ruigrok, Journalism of attachment, p. 2.

47 Ruigrok, Journalism of attachment, backcover.

$48 \mathrm{~J}$. Wieten, 'Srebrenica en de journalistiek. Achtergronden en invloed van de berichtgeving over het conflict in voormalig Joegoslavië', in: Srebrenica, een 'veilig' gebied. Reconstructie, achtergronden, gevolgen en analyses van de val van een Safe Area, Niod, Amsterdam 2002, p. 99.

49 M. Huygen, 'Pers over Srebrenica: tussen actie en afstand', NRC, I3 April 2002. http://vorige.nrc.nl/dossiers/ srebrenica/niodrapport/articleI563463.ece/Pers_over_Srebrenica_tussen_actie_en_afstand (accessed I2 February and I8 October 20I3).

50 A. de Graaf, 'Een nieuwe dag, een nieuwe krant. Een kwalitatief onderzoek naar zelfreflectie bij vijf Nederlandse dagbladen naar aanleiding van het NIOD-rapport over Srebrenica', in: Medialogica: over het krachtenveld tussen burgers, media en politiek, Sdu Uitgevers, Den Haag 2003, p. 29I-309, p. 302.

5I Schudson, The sociology of news, p. 35.

52 D. Dungaciu, "East and West and the "mirror of nature": nationalism in West and East Europe - essentially different?', in: A decade of transformation, IWM Junior Visiting fellows conferences, 8, I999.

53 M. Billig, 'Reflecting on a critical engagement with banal nationalism' - reply to Skey', in: The sociological review, 57, 2009 , p. 347-352, p. 348 .

54 Van Loon, 'Griekenland moet met EG situatie op Balkan stabiliseren'.

55 The data on which these numbers have been based can be found on http://www.jhsg.nl/extras/michelvanduijnen_ bijlage.pdf (accessed 20 February 2013). 